\title{
The Technological-Pedagogical Knowledge for In-Service Teachers in Primary Education: A Systematic Literature
}

\section{Review}

\author{
Miguel Angel Paidican ${ }^{{ }^{*}}$ \\ (D) 0000-0003-0696-054X \\ Pamela Alejandra Arredondo ${ }^{2}$ \\ (D) 0000-0002-4888-4584 \\ ${ }^{1}$ University of Barcelona, Barcelona, SPAIN \\ 2 University of Granada, Granada, SPAIN \\ * Corresponding author: mpaidican@gmail.com
}

Citation: Paidican, M. A., \& Arredondo, P. A. (2022). The Technological-Pedagogical Knowledge for In-Service Teachers in Primary Education: A Systematic Literature Review. Contemporary Educational Technology, 14(3), ep370. https://doi.org/10.30935/cedtech/11813

\section{ARTICLE INFO}

Received: 7 Jul 2020

Published: 10 Feb 2022

\begin{abstract}
This article presents the results of a scientific literature analysis based on Kitchenham's (2004) proposal, regarding the technological-pedagogical knowledge of the content under the TPACK model. Research studies containing data-driven information in primary education were revised. The selection of the 622 articles was conducted in Scopus, WoS (Web of Science), ERIC (Educational Resources Information Center), and Google Scholar databases; considering the period from which this model was initially described to May 2019. The following criteria were also observed: open access sources, referring to social sciences, and full text available. To conclude, there is limited scientific production regarding TPACK model in primary education, with 3,05\% of the articles reviewed in this systematic literature review. An increase in using the TPACK model in terms of teacher knowledge and enriched environments with information and communication technology has also been observed. Participation of other members of the school community as students, parents and managers is also recommended.
\end{abstract}

Keywords: knowledge of teachers, educational technology, knowledge of technological pedagogical content (TPACK), primary school teachers, teacher training, Integration of technology

\section{INTRODUCTION}

Social, economic and technological developments have provided an interesting field of research to explore the integration of information and communication technologies (ICT) in education.

Since the mid-1980s, the ideas of Schulman $(1986,1987)$ have contributed to a line of research that aims to provide a conceptual and contextual framework for the construction of teachers' knowledge. Didactic content knowledge has become a key issue in initial and in-service teacher education programmes.

Subsequently, Mishra and Koehler's (2006) study involves the introduction of a model that involves linking didactic content knowledge with technology. The technological, pedagogical and content knowledge (TPACK) model evidences the dynamic integration of the three essential dimensions in such a way as to reconcile instruction, context and technology (Koehler \& Mishra, 2009). It is worth noting that Mishra and Koehler's (2006) article, published in Teachers College Record in 2006, is the most relevant, being cited 12,500 times. In TPACK, three central dimensions can be distinguished and the intersection between them allows for the identification of four others, which are shown in Figure 1:

Copyright $\odot 2022$ by authors; licensee CEDTECH by Bastas, CY. This article is an open access article distributed under the terms and conditions of the Creative Commons Attribution License (http://creativecommons.org/licenses/by/4.0/). 


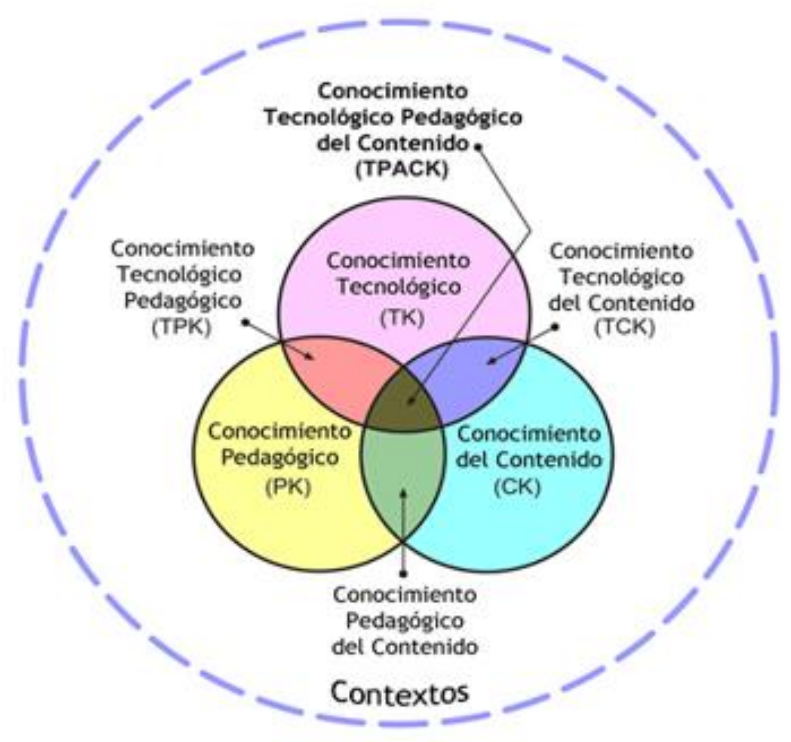

Figure 1. Illustration of technological pedagogical content knowledge (TPACK) (Source: http://tpack.org)

1. Technological literacy (TK): These are the skills required to use ICT tools such as computers, projectors, camera, digital video, whiteboards, internet and the skills to use different software programs (Koehler et al., 2014; Munyengabe et al., 2017).

2. Content knowledge (CK): These are skills related to the content to be taught. It should be noted that teaching and learning processes are enhanced to the extent that teachers present knowledge in meaningful contexts (Mishra \& Koehler, 2006; Munyengabe et al., 2017).

3. Pedagogical knowledge (PC): Teachers require knowledge of teaching and learning processes, which should include classroom management, planning and evaluation of teaching and learning processes (Munyengabe et al., 2017; Schmidt et al., 2008).

4. Pedagogical content knowledge (PCK): Occurs at the intersection of CK and PK, as PCK prepares CK for the teaching process (Koelher et al., 2014; Munyengabe et al., 2017; Shulman, 1986).

5. Technological content knowledge (TCK): The result of the combination of TK and CK, TCK relates how technology can show specific content (Koelher et al., 2014; Munyengabe et al., 2017; Schmidt et al., 2008).

6. Technological pedagogical knowledge (TPK): The result of the combination of TK and PK, TPK refers to how various technologies can be used and how teachers deliver content (Mishra \& Koehler, 2006; Munyengabe et al., 2017; Schmidt et al., 2008).

7. Technological pedagogical content knowledge (TPACK): Corresponds to the result of the intersection of CK, PK and TK, which represents the knowledge that teachers must possess to integrate ICT into the teaching and learning process (Koehler et al., 2014; Munyengabe et al., 2017; Schmidt et al., 2008).

The TPACK model has consolidated its importance in educational research, providing theoretical guidance in teacher education in areas of technology (Erdogan \& Sahin, 2010; Graham, 2011; Jang \& Tsai, 2012; Lescano, 2013; Lye, 2013; Nordin et al., 2013; Voogt et al., 2013; Wang et al., 2018). In addition, TPACK is a pedagogical way of knowing how to teach content using the most appropriate technology for the teaching subject (Mishra \& Koehler, 2006; So \& Kim, 2009). Another usefulness of the TPACK model is related to the integration of ICT in the classroom, considering teachers' perceptions as a guide for the development of the process (Kim et al., 2013; Kohn \& Chai, 2014; Lin et al., 2013).

So far, systematic reviews of TPACK address aspects related to initial and ongoing training, ICT integration, online teaching, and contextual features (Chai et al., 2013; Moore-Adams et al., 2016; Rosenberg \& Koehler, 2015; Voogt et al., 2013), for the present review aims to analyze the scientific literature related to TPACK in primary education. It should be noted, the following systematic literature review (SLR) is developed as part of 
Table 1. Stages described in this SLR

\begin{tabular}{ll}
\hline Stages & Activities \\
\hline Stage 1: Planning the SLR & Activity 1.1: Identifying the rationale of the SLR \\
& Activity 1.2: Developing a protocol for the SLR \\
Stage 2: Conducting the SLR & Activity 2.1: Identifying the purpose of the SLR \\
& Activity 2.2: Selecting primary study sources \\
& Activity 2.3: Evaluating the quality of study sources \\
& Activity 2.4: Data collection and monitoring \\
& Activity 2.5: Data synthesis \\
Stage 3: Reporting the SLR & Communicating results of the SLR \\
\hline
\end{tabular}

the master's thesis at the University of Granada and its subsequent use in the PhD "Education and Society" at the University of Barcelona.

Therefore, the following research questions aim to examine the state of the art of the TPACK model in primary education, based on the approach proposed by Kitchenham (2004):

1. Question 1: What studies can be found in the scientific literature regarding the TPACK model and inservice primary teachers?

2. Question 2: What methodological orientations do TPACK model studies describe regarding in-service primary teachers?

3. Question 3: What recommendations does scientific literature suggest about the TPACK model and inservice primary teachers?

4. Question 4: What further areas of research can be developed from this literature review?

\section{MATERIALS AND METHODS}

An SLR aims through a scientific method to limit bias by means of critical and structured evaluation following a predefined protocol (Petticrew \& Roberts, 2006). In this study, SLR was carried out following the stages defined by Kitchenham (2004), which are described in Table 1.

\section{Planning and Conducting the SLR}

A research of SLR related to the area of study was carried out in the international databases WoS, SCOPUS, and Google Scholar in order to identify studies related to the TPACK model in primary education. No SLR were found in the schooling stage but research conducted in initial teacher training and continuous development (Chai et al., 2013; Moore-Adams et al., 2016; Rosenberg \& Koehler, 2015; Voogt et al., 2013).

Chai et al. (2003) considers 74 SLR articles focusing on the integration of ICT and TPACK model, suggesting potential areas for further development. Voogt et al. (2013) analyzed 55 articles that focus on theoretical bases and TPACK practices, concluding that integration of ICT conditions teachers' knowledge and beliefs about pedagogy and technology. Rosenberg and Koehler (2015) examined 193 articles relating the TPACK model to features of the geographical context, school and classroom, concluding that this model develops over the background. Moore-Adams et al. (2016) analyzed 26 studies regarding TPACK and knowledge and skills required to teach online, finding that teachers are not fully prepared for online teaching and learning processes.

Consequently, a systematic literature review was necessary. This revision was conducted between March and May 2019 in the following international databases: SCOPUS, WoS (Web of Science), ERIC (Educational Resources Information Center), and Google Scholar. These databases were considered as were reported in other SLR about TPACK model (Chai et al., 2013; Dikmen \& Demirer, 2016; Rodríguez et al., 2019; Voogt et al., 2013; Willermark, 2018).

This SLR revises articles from 2006 to May 2019. Keywords were verified in ERIC and UNESCO Thesaurus before researching the databases. Table 2 depicts the specific protocol of keywords used when researching in each database.

We used the following research criteria to determine the documents for revision: only empirical articles, complete text, in the social sciences area, and regarding schools and primary education. Exclusion criteria follow editorials, press notes, conference papers, reports, MA and PhD dissertations, other fields of study, 
Table 2. Specific protocol of keywords in each database

\begin{tabular}{ll}
\hline Database & Protocol \\
\hline SCOPUS & TITLE-ABS-KEY(technological AND pedagogical AND content AND knowledge ) OR TITLE-ABS-KEY(tpack) \\
WoS & TS=(technological AND pedagogical AND content AND knowledge) OR TS=(tpack) \\
ERIC & technological AND pedagogical AND content AND knowledge OR tpack \\
Google Scholar & ALLINTITLE: technological pedagogical content knowledge OR TPACK \\
\hline
\end{tabular}

Table 3. Overview of the selected research articles

\begin{tabular}{lcccc}
\hline Database & Advanced search & Duplicated & 1st selection & 2nd selection \\
\hline SCOPUS & 103 & 9 & 94 & 10 \\
WOS & 206 & 46 & 160 & 5 \\
ERIC & 237 & 27 & 210 & 4 \\
Google Scholar & 161 & 3 & 158 & 0 \\
Total & $\mathbf{7 0 7}$ & $\mathbf{8 5}$ & $\mathbf{6 2 2}$ & $\mathbf{1 9}$ \\
\hline
\end{tabular}

and restricted access to the institution, abstracts, and different educational levels. The initial search provided 707 documents, analysing titles, keywords, and abstracts regarding the inclusion criteria. Therefore, 85 duplicate articles (13.6\%) were found, as described in Table 3.

From these 622 selected articles, most of them were found in ERIC (210) and WoS (160) databases. Titles, keywords, and abstracts referring to the inclusion criteria were revised, being necessary to access to some full texts. In total, 19 articles study the TPACK model in primary education, 10 of which are indexed in SCOPUS, 5 in WoS, and 4 in ERIC. These articles were fully read to determine how the TPACK model was applied, obtaining information systematically about the research questions previously defined. Table 4 depicts the list of articles included in this SLR.

Table 4. Research articles included in the SLR

\begin{tabular}{|c|c|c|c|c|c|c|}
\hline Author (year) & Country & Type of study & Research design & $\begin{array}{c}\text { Population \& } \\
\text { sample }\end{array}$ & Instruments & Analyzed area \\
\hline $\begin{array}{l}\text { Angeli et al. } \\
(2016)\end{array}$ & USA & Empirical study & $\begin{array}{c}\text { Computing science } \\
\text { program }\end{array}$ & $\begin{array}{l}\text { 6-12-year-old } \\
\text { students }\end{array}$ & $\begin{array}{c}\text { Weekly meetings } \\
\text { for curricular } \\
\text { design }\end{array}$ & $\begin{array}{l}\text { Computational } \\
\text { thinking }\end{array}$ \\
\hline $\begin{array}{l}\text { Ballesta et al. } \\
\text { (2017) }\end{array}$ & Spain & Mixed-methods & $\begin{array}{c}\text { Quasi- } \\
\text { experimental }\end{array}$ & $\begin{array}{c}53 \text { Students, } 11 \\
\text { Teachers, \& } 28 \\
\text { Families }\end{array}$ & Pre- \& post-test & No data \\
\hline $\begin{array}{l}\text { Bingimlas } \\
(2018)\end{array}$ & Saudi Arabia & Quantitative & Non-experimental & $\begin{array}{l}243 \text { Primary } \\
\text { teachers \& } \\
116 \text { Students }\end{array}$ & $\begin{array}{l}\text { TPACK-based } \\
\text { questionnaire }\end{array}$ & No data \\
\hline $\begin{array}{l}\text { Chen and } \\
\text { Jang (2013) }\end{array}$ & Taiwan & Quantitative & Non-experimental & $\begin{array}{l}689 \text { Primary } \\
\text { teachers }\end{array}$ & Survey & $\begin{array}{l}\text { Mathematics \& } \\
\text { science }\end{array}$ \\
\hline $\begin{array}{l}\text { Hansen et al. } \\
\text { (2016) }\end{array}$ & England & $\begin{array}{l}\text { Design-based } \\
\text { research (DBR) }\end{array}$ & Interactive design & $\begin{array}{l}23 \text { Primary } \\
\text { teachers }\end{array}$ & $\begin{array}{l}\text { Workshop \& focus } \\
\text { group }\end{array}$ & Mathematics \\
\hline $\begin{array}{l}\text { Heitink et al. } \\
\text { (2017) }\end{array}$ & Netherlands & Mixed-methods & Case study & $\begin{array}{l}29 \text { Primary } \\
\text { teachers }\end{array}$ & $\begin{array}{c}\text { Videos \& } \\
\text { questionnaire }\end{array}$ & No data \\
\hline Jones (2017) & USA & Qualitative & Case study & $\begin{array}{l}4 \text { Primary } \\
\text { teachers }\end{array}$ & $\begin{array}{l}\text { Interview \& } \\
\text { observation }\end{array}$ & No data \\
\hline $\begin{array}{l}\text { Kazu and } \\
\text { Erten (2014) }\end{array}$ & Turkey & Quantitative & $\begin{array}{l}\text { Non-experimental, } \\
\text { Exploratory } \\
\text { method }\end{array}$ & $\begin{array}{l}280 \text { Primary } \\
\text { teachers }\end{array}$ & $\begin{array}{l}\text { TPACK-based } \\
\text { questionnaire }\end{array}$ & No data \\
\hline Liu (2013) & Taiwan & Qualitative & $\begin{array}{c}\text { Teacher } \\
\text { professional } \\
\text { development } \\
\text { (TPD) program }\end{array}$ & $\begin{array}{l}6 \text { Primary } \\
\text { teachers }\end{array}$ & $\begin{array}{l}\text { Observation \& } \\
\text { focus group }\end{array}$ & $\begin{array}{c}\text { Language \& } \\
\text { literature, English } \\
\text { language, Social } \\
\text { studies science \& } \\
\text { technology, } \\
\text { Mathematics, Life } \\
\text { curriculum }\end{array}$ \\
\hline $\begin{array}{l}\text { Lye et al. } \\
\text { (2014) }\end{array}$ & Singapur & Mixed-methods & Case study & $\begin{array}{l}35 \text { Fourth- \& } \\
\text { fifth-grade } \\
\text { students }\end{array}$ & $\begin{array}{l}\text { Survey, interview, } \\
\text { \& focus group }\end{array}$ & $\begin{array}{l}\text { Computational } \\
\text { thinking }\end{array}$ \\
\hline $\begin{array}{l}\text { Maboe et al. } \\
\text { (2018) }\end{array}$ & South Africa & Qualitative & Case study & $\begin{array}{l}12 \text { Students, } 6 \\
\text { Teachers, \& } 6 \\
\text { Families }\end{array}$ & $\begin{array}{l}\text { Interview \& focus } \\
\text { group }\end{array}$ & English language \\
\hline
\end{tabular}


Table 4 (Continued). Research articles included in the SLR

\begin{tabular}{|c|c|c|c|c|c|c|}
\hline Author (year) & Country & Type of study & Research design & $\begin{array}{c}\text { Population \& } \\
\text { sample }\end{array}$ & Instruments & Analyzed area \\
\hline $\begin{array}{l}\text { Magen- } \\
\text { Nagar \& } \\
\text { Peled (2013) }\end{array}$ & Israel & Quantitative & Non-experimental & $\begin{array}{c}881 \text { Primary } \\
\text { teachers }\end{array}$ & Questionnaire & Primary general \\
\hline $\begin{array}{l}\text { Munyengabe } \\
\text { et al. (2017) }\end{array}$ & Rwanda & Qualitative & Non-experimental & $\begin{array}{l}30 \text { Primary } \\
\text { teachers }\end{array}$ & $\begin{array}{c}\text { TPACK-based } \\
\text { questionnaire, } \\
\text { interview, \& focus } \\
\text { group }\end{array}$ & Different areas \\
\hline $\begin{array}{l}\text { Paneru } \\
(2018)\end{array}$ & Chequia & Qualitative & Phenomenological & $\begin{array}{l}12 \text { Primary } \\
\text { teachers }\end{array}$ & $\begin{array}{c}\text { Observation \& } \\
\text { interview }\end{array}$ & English language \\
\hline $\begin{array}{l}\text { Roig-Villa et } \\
\text { al. (2015) }\end{array}$ & Spain & Quantitative & Non-experimental & $\begin{array}{l}224 \text { Primary } \\
\text { teachers }\end{array}$ & $\begin{array}{l}\text { TPACK-based } \\
\text { questionnaire }\end{array}$ & No data \\
\hline $\begin{array}{l}\text { Sáez-López } \\
\text { and Cózar- } \\
\text { Gutiérrez } \\
\text { (2017) }\end{array}$ & Spain & $\begin{array}{l}\text { Design-based } \\
\text { research (DBR) }\end{array}$ & Natural approach & $\begin{array}{l}46 \text { Sixth-grade } \\
\text { students }\end{array}$ & Questionnaire & Social sciences \\
\hline Tai (2015) & Taiwan & Mixed-methods & $\begin{array}{c}\text { Convergence } \\
\text { model }\end{array}$ & $\begin{array}{l}24 \text { primary } \\
\text { teachers }\end{array}$ & $\begin{array}{c}\text { Survey, } \\
\text { questionnaire, } \\
\text { observation list, } \\
\text { interview, \& focus } \\
\text { group }\end{array}$ & English language \\
\hline $\begin{array}{l}\text { Vatanartiran } \\
\text { (2015) }\end{array}$ & Turkey & Quantitative & Non-experimental & $\begin{array}{c}441 \text { Primary } \\
\text { teachers }\end{array}$ & $\begin{array}{l}\text { TPACK-based } \\
\text { questionnaire }\end{array}$ & No data \\
\hline $\begin{array}{l}\text { Wong et al. } \\
(2014)\end{array}$ & Singapur & $\begin{array}{l}\text { Design-based } \\
\text { research (DBR) }\end{array}$ & Experimental & $\begin{array}{l}259 \text { Third-grade } \\
\text { students }\end{array}$ & $\begin{array}{l}\text { Study plan in } \\
\text { MyCLOUD }\end{array}$ & Chinese language \\
\hline
\end{tabular}

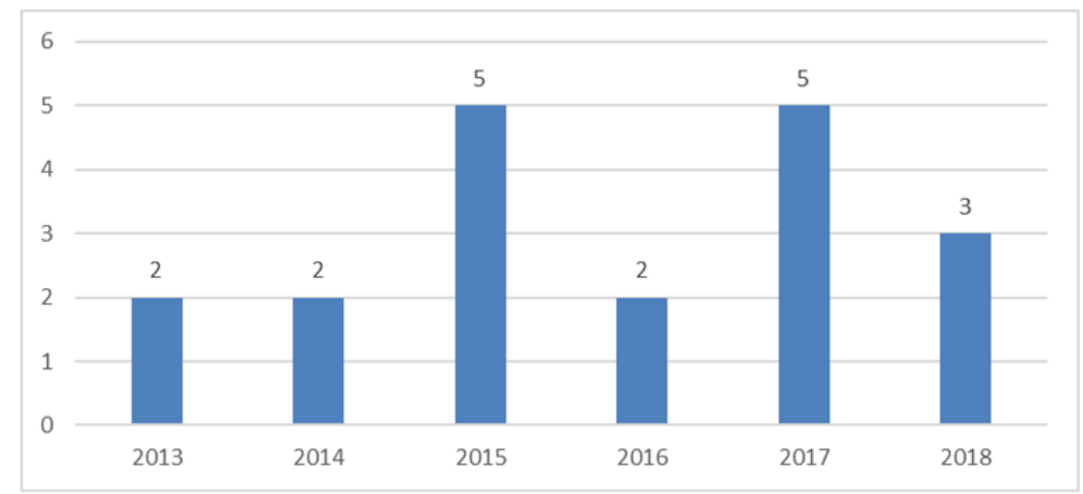

Figure 2. TPACK articles according to the year of publication

\section{RESULTS}

Initially, bibliometric indexes describing the year of publication, geographical distribution, type, and design study of each research were analyzed. Subsequently, TPACK model approaches to primary education were revised based on the teachers' knowledge, students' learning, and in the other members of the school community.

\section{Bibliometric Indexes of the TPACK Model in Primary Education}

Each SLR requires bibliometric indexes in its initial stage. According to Ardanuy (2012), they permit to express quantitatively the features present in the documents and, thus, analyze some aspects of this scientific activity.

Studies reporting TPACK model in primary education have been published between the years 2013 and 2018 (Figure 2). It is important to highlight that most of the articles informing this topic were published between 2015 and 2017 (five papers in each year, respectively). 


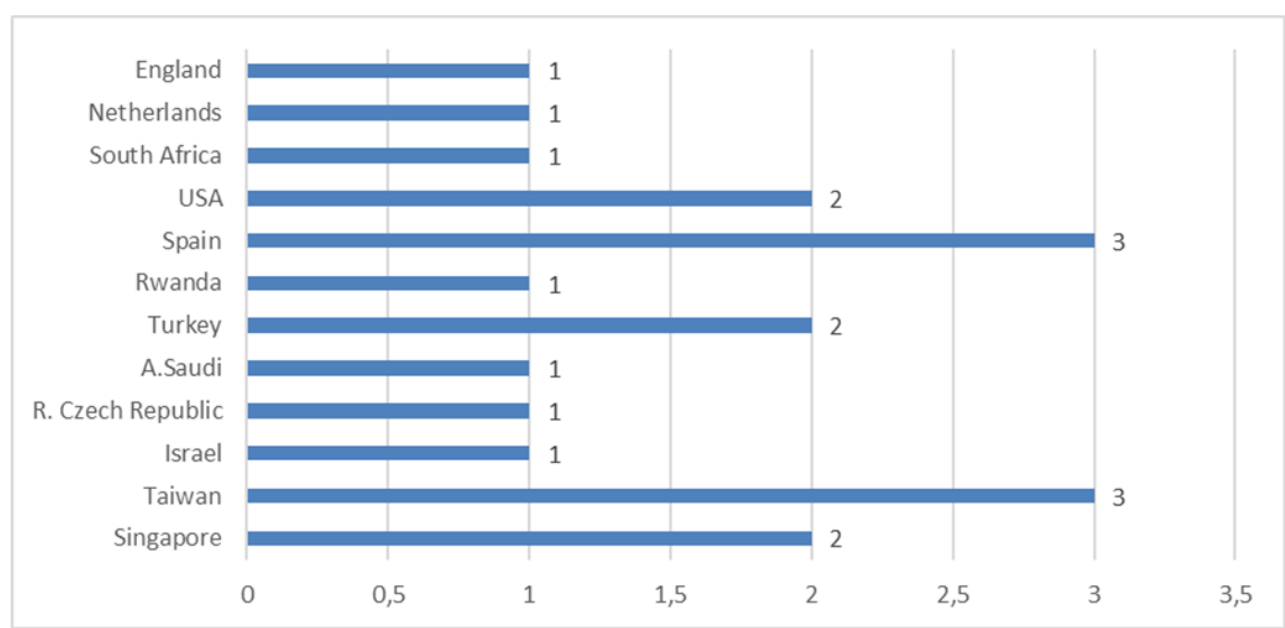

Figure 3. Geographical distribution of selected publications

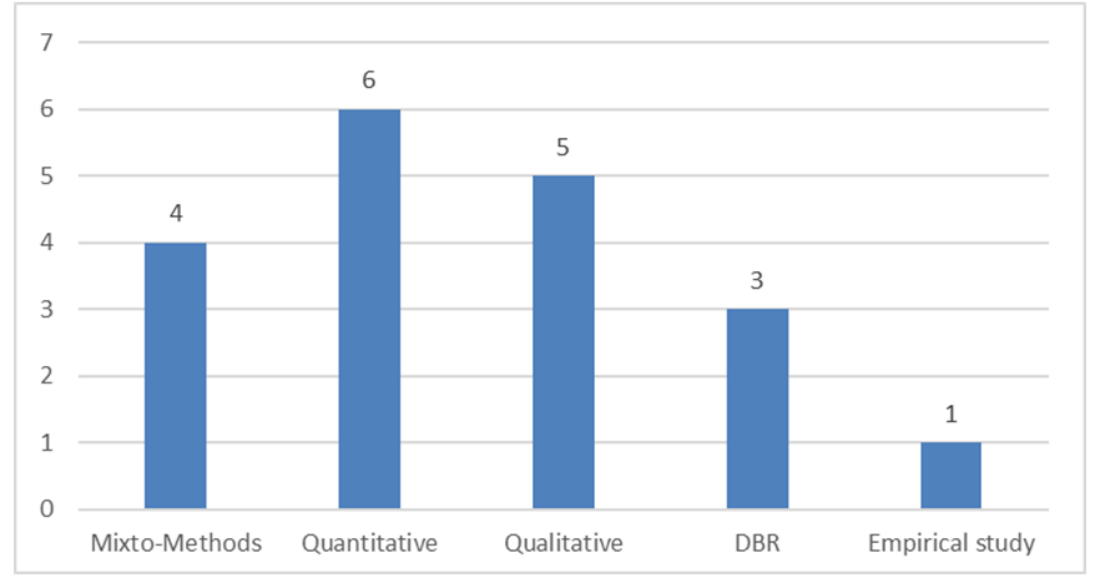

Figure 4. Types of research found in this SLR

Regarding their geographical distribution, articles published in Europe (9), Asia (6), Africa (2), and America (2) outline. Furthermore, the countries with more contributions were Spain and Taiwan (with three articles each), Turkey, the US, and Singapore (with two each), and other seven countries with one publication each (Figure 3).

Regarding the type of research, quantitative studies outline with six studies, followed by qualitative research (5) and mixed-methods (4). Additionally, design-based research (3) and an empirical study (1) was found (Figure 4).

With reference to the research design, six (6) non-experimental studies, four (4) case-studies, one (1) quasiexperimental, and one (1) experimental were found. Other mixed studies or with no explicit design as one convergence model, an interactive-design study, and one based on the natural approach was observed (Figure 5).

Regarding the participants involved in each research, samples vary from four to 811; with a predominance of studies with less than 300 participants (84.21\%). Major sampling highlight in quantitative studies conducted in Israel by Magen-Nagar and Peled (2013), with 811 primary school teachers selected randomly and in Taiwan (Chen \& Jang, 2013), where the research was conducted with 689 primary teachers.

On the other hand, within qualitative research, Munyengabe et al. (2017) conducted a study in Rwanda with 30 primary teachers. Regarding mixed-methods, Lye et al. (2014) project involved 34 participants. Moreover, design-based research considered a sample of 259 primary students in a non-experimental study (Wong et al., 2014). 


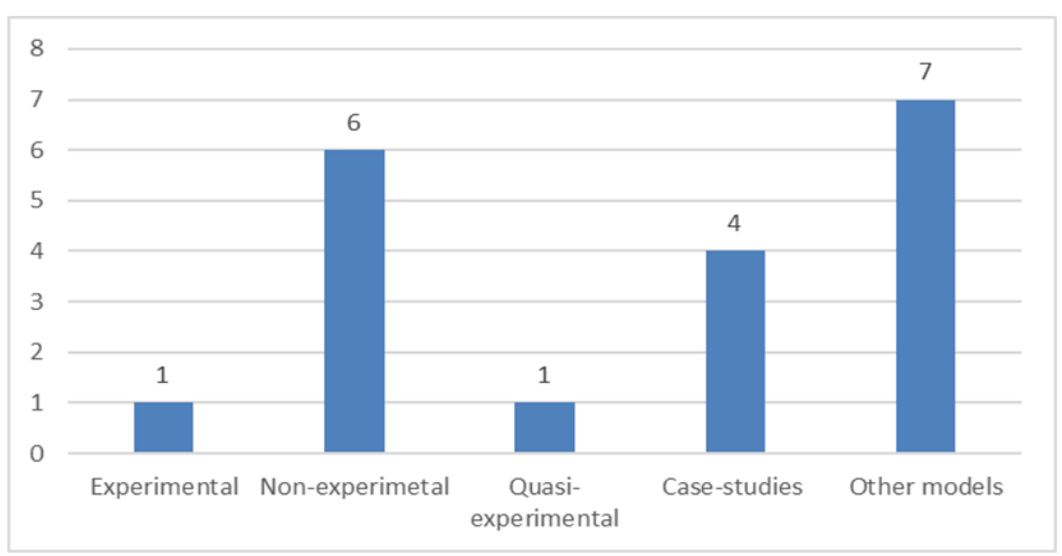

Figure 5. Types of research design in TPACK

Table 5. Teacher-centered approaches to TPACK research

\begin{tabular}{llc}
\hline TPACK approach & Authors & Quantity/percentage \\
\hline Self-reporting of teachers' & Bingimlas (2018), Chen \& Jang (2013), Kazu \& Erten (2014), Magen- & $6(42.8 \%)$ \\
knowledge TPACK & Nagar \& Peled (2013), Roig-Villa et al. (2015), \& Vatanartiran (2015) & $2(14.8 \%)$ \\
TPACK teacher training & Liu (2013) \& Tai (2015) & $4(28.5 \%)$ \\
$\begin{array}{l}\text { TPACK teaching } \\
\text { experiences }\end{array}$ & Hansen et al. (2016), Heitink et al. (2017), Munyengabe et al. (2017), \\
$\begin{array}{l}\text { TK development \& its } \\
\text { relationship with TPACK }\end{array}$ & \& Paneru (2018) & $1(7.1 \%)$ \\
\hline
\end{tabular}

Research instruments, Munyengabe et al. (2017), Roig et al. (2015), and Vatanartiran (2015), applied the TPACK questionnaire developed and validated by Schmidt et al. (2009) according to Rosenberg and Koehler (2015).

\section{Approaches Towards the TPACK Model in Primary Education}

The results obtained in this SLR highlight the existence of diverse approaches in research related to TPACK, teachers' knowledge, learning processes, and school community management. Consequently, this SLR describes three approaches to the TPACK model: teachers, students, and school community.

\section{Teachers' approaches towards the TPACK model}

There are 13 articles (68.42\%) focused on teachers, the present analysis uses the guidelines of Paidican (2019) and Willermark (2017), in Table 5 the classification is observed.

The self-report approach, consisting of a self-assessment through a survey, uses a Likert scale of 3 to 7 points, teachers must numerically rate the statements of the three core and four secondary dimensions that make up the TPACK. The most widely used instrument was developed by Schmidt et al. (2009) in five research studies, one translated into Turkish by Ozturk and Horzum (2011). When referring to the length of the surveys, the average is 39 items, the lowest number is 29 items by Roig-Villa et al. (2015) and the highest is 47 items by Vatanartiran (2015). Four researches present their reliability indices, the average reaches a Cronbach's alpha (0.84), the highest being (0.96) by Kazu and Erten (2014), and the lowest (0.70) by Chen and Jang (2013).

In relation to the population, the average number of participants is 420 individuals, the most representative sample is the research of Magen-Nagar and Peled (2013) and the smallest Bingimlas (2018). The six researches are quantitative and non-experimental, regarding data analysis, three researches Bingimlas (2018), Chen and Jang (2013), and Vatarnartiran (2015) perform analysis of variance (ANOVA), while the remaining researches develop exploratory, correlational analysis and structural equation modelling (SEM). The most studied variables are gender, age and years of experience of the teachers.

In relation to the results, the studies by Bingimlas (2018) and Roig-Villa et al. (2014) agree. For their part, science teachers obtain higher results in TPACK, in contrast to mathematics teachers. In addition, teachers point out that a good attitude is not enough to use ICT (Chen \& Jang, 2013), they are aware that ICT facilitates students' autonomous learning (Magen-Nagar \& Peled, 2013), teachers' perception of digital knowledge has 
significant effects on other knowledge (Vatarnartiran, 2015), 32\% of teachers who use ICT recognize them as convenient (Bingimlas, 2018), and furthermore, that ICT use affects PCK and its sub dimensions (Kazu \& Erten, 2014).

The present SLR analyses two research studies focused on teacher training, in relation to the research design they are oriented towards teacher professional development (TPD) and training workshops TPACK in Action, CALL (computer assisted language learning).

The studies show samples of between 6 and 24 cases, there is a greater participation of women, the age of the teachers ranges between 30 and 40 years with more than $60 \%$, and $70 \%$ of the teachers have between 6 and 16 years of professional experience.

The preferred subject is English, although there is also participation of teachers of seven other subjects (Liu, 2013). The most commonly used instrument is classroom observation, although Tai's (2015) study considers questionnaires, reflections, interviews, document analysis and the application of pre- and post-tests for data collection.

As for the procedure used for teacher training, 15-hour workshops are considered (Tai, 2015) and the rigorousness of Liu's (2013) work is highlighted, establishing four stages: course design integrating CK, PK, and TK, lesson design in the TPACK framework, observation of peer teachers, and sharing in a discussion forum.

With regard to the results, according to Tai (2013), TPACK facilitates the measurement of impact on the effectiveness of $\mathrm{CK}, \mathrm{PK}$, and TK in the training process, but its structure must include modelling, analysis, demonstration, application and reflection. For Liu (2013), the participation of teachers in training processes facilitates the change of beliefs and their way of integrating new technologies.

About the research related to teaching experiences, two are qualitative, a case study and an interactive design focused on TPACK. The samples range from 16 to 30 teachers. The studies are in subjects such as mathematics and English. The most commonly used instruments are: interviews, workshops, focus groups and observations, highlighting the research of Hansen et al. (2016) and Munyengabe et al. (2017) where the same instruments are applied.

In relation to the procedures, TPACK is used for initial stages of training Hansen et al. (2016) and Munyengabe et al. (2017) and in the integrated model (TPACK in action) by Paneru (2018).

Research findings indicate that policies such as one laptop per child (OLPC) require the participation of teachers for their successful development (Heitink et al., 2017; Munyengabe et al., 2017). Also, the use of cooperative approaches enhances teachers' creativity and context-specific adaptation facilitates the development of better teaching practices (Hansen et al., 2016).

Regarding the development of TK and its relationship with TPACK, the qualitative research of Jones (2017), a case study with the participation of four teachers, is presented. Interviews, observations, lesson plans, field notes, focus groups, and reflections are used for data collection. The results show that low TK limits the use of ICT and represents the main problem in promoting innovative practices in ICT integration. In addition, the poor TK reduces the possibilities of carrying out teaching practices that consider constructivist and socioconstructivist aspects.

\section{Students" approaches towards TPACK model}

There are four articles focus on students (21.05\%), there are two design-based researches, one empirical study and one mixed study with conventional content analysis. The samples range from 35 to 259 students, with a higher participation of fourth and fifth grade students (Lye et al., 2014; Wong, 2015). Computer science is the subject with the most studies with two, followed by Chinese language and social studies.

The data collection instruments are different, highlighting the case of Sáez-López (2015) who use Rubric TPACK based on Harris (2009) and questionnaire based on TPACK and Bloom's taxonomy. In addition, the use of activity design (TPD) and lesson plans is considered (Angeli et al., 2016; Wong, 2015). The most recurrent procedures are design and implementation, the duration ranges from three to 20 hours.

The results show that TPACK facilitates the design, planning and integration of CK, PK, and TK knowledge so that students can access higher order learning according to Bloom's taxonomy (Lye et al., 2014; Sáez-López, 2015). Also, students report recognizing virtual environments and 3D simulation as learning spaces (Lye et al., 
2014; Wong, 2015). Finally, according to Angeli et al. (2016), the gradual adoption of computer science in primary schools represents the basis for expanding knowledge in the coming years.

\section{School community approaches towards TPACK model}

There are two TPACK studies focused on the school community (10.52\%), the research is developed through mixed and qualitative methods. The samples consider the participation of teachers, students and families, the most representative being Ballesta et al. (2017). The research work is carried out in the subjects of English and Spanish. When referring to the research instruments, the interview, focus group, field diary and, pre- and post-test are used. The resources used for the development of the studies are Ipad, Ebook, and MetamojiShare App. The procedure considers four phases, the problem, design, and information, development and data collection. It also considers the participation of parents in the classroom.

The results show that TPACK can be used in a wide range of school contexts. In addition, involving families allows fostering the development of students' digital competences (Ballesta et al., 2017; Maboe et al., 2018).

The use of TPACK facilitates the adaptation of digital material, at PK and CK levels (Ballesta et al., 2017). Finally, students have difficulties in developing reading skills without using ICT (Maboe et al., 2018).

\section{DISCUSSION}

The TPACK model has continued to produce scientific literature in recent years, although this is not the case in primary education, according to Margerum-Leys and Marx (2002), teacher training programs in ICT have traditionally focused on tertiary and secondary education; especially on the CK component.

In relation to the results of the research reviewed, they show that teachers present higher PK and CK knowledge compared to TK and their interactions, which is consistent with previous research Archambault and Barnett (2010), Beltrán (2019), Cabero et al. (2015), Da Silva et al. (2015), Paidicán (2017), Roig et al. (2015), Roussinos \& Jimoyiannis (2019), and Schmidt et al. (2009).

On the other hand, females perform better on most TPACK dimensions with the exception of TK, as suggested by Akturk and Ozturk, (2019), Lin et al. (2013), and Luik et al. (2018). It should be noted that there is research related to TPACK where males have higher levels of knowledge than females (Chai et al., 2010; Karatas, 2014).

In relation to teachers' willingness to use ICT, they have a positive attitude and high motivation, although it is insufficient for the use of ICT. Furthermore, in highly technological environments, teachers have greater ICT skills, similar to the ideas put forward by Ertmer and Ottenbreit-Leftwich (2010), who state that teachers do not use technology due to a lack of access and training.

When referring to the ICT tools used by teachers, they vary according to the content to be addressed. Therefore, the use of TPACK facilitates aspects related to planning, classroom management, and student needs, ideas similar to those put forward by Hjalmarson and Diefes-Dux (2008) and Margerum-Leys and Marx (2002). In addition, the right design, implementation, and instruction related to the technological, pedagogical and curricular, favour the achievement of higher learning by students, agreeing with previous studies Harris and Hofer (2011), Hughes (2005), Koehler and Mishra (2005, 2009), Niess (2005), and Yeh et al. (2021).

As for professional teacher training, there are initiatives in primary education related to TPACK, but they are underdeveloped. The initiatives of classroom observation and integration of Montessori schools can be highlighted. Teachers point out the need for digital literacy in order to acquire new skills, abilities, and competencies and promote changes in their mentality, which allows them to improve their teaching practice. Echoing Brantley-Dias and Ertmer (2013), who argue that TPACK research should have as its fundamental purpose to understand the knowledge teachers need to make use of technologies.

When referring to student-centered TPACK studies, students' views indicate that they enjoy activities that consider the use of simulators and virtual environments. Moreover, students consider that ICT favors their learning, which represents a challenge for schools, as teachers need to understand that integrating ICT requires some pedagogical adaptations and family involvement. For Hjalmarson and Diefes-Dux (2008), teachers are aware of the learning needs and requirements of their students, which contributes to designing effective teaching practices within the classroom. 
In relation to TPACK research focused on the school community, it is underdeveloped, although early findings show that the involvement of diverse school stakeholders supports the development of students' digital competencies, according to Koehler and Mishra (2009), TPACK offers opportunities to analyze the complex phenomenon of ICT integration.

When referring to the recommendations focused on teachers, it is suggested to carry out TPACK studies related to professional development programs considering: collaborative spaces among teachers, adequate time extension, advanced ICT approaches, the incorporation of attitudinal competences and open training environments. In addition, develop TPACK studies related to the evaluation of hardware and technological infrastructure used by teachers and the implementation of intervention projects based on learning models and activities related to CK, PK, and TK.

From the studies focused on students, it is recommended to develop research that complements the TPACK model with other theoretical perspectives, such as Bloom's taxonomy, Montessori method, among others. In addition, adaptations of digital teaching material should be made based on the TPACK model, relating PK, CK, and TK. It is also proposed to use TPACK for the implementation of computer science in primary school and its relationship with other subjects.

Finally, in relation to the studies of the school community, it is necessary to investigate the guarantees of access that families have to technological resources. Regarding the potential areas that could be developed based on SR, the following are alternatives: to know and compare the efforts made by teachers when planning, designing and implementing ICT, to know the impact of using TPACK in the design of activities for students with learning difficulties in areas such as reading and mathematics, and to confirm the relationship between TK and TPK of teachers and students.

In addition, implement through TPACK working communities in the areas of didactics and school management, involving teachers, principals, teachers, students and families, implement the use of TPACK of self-learning systems that involve the entire educational community and know the impact of the use of video clip in the initial and continuous training of teachers.

\section{CONCLUSIONS}

From the SLR, we can conclude that only 19 of the 622 articles reviewed relate to the TPACK model in primary education, which represents $3.05 \%$. This shows the scarce scientific production at this educational level. For example, no research has been found on the TPACK model in Latin America.

The TPACK model is versatile, as it not only describes teachers' perceptions of knowledge, but also the importance of peer collaboration in the design and implementation of teacher education programs.

As for the methodological aspects of the TPACK model, it is used to design and implement digital environments, highlighting the importance of teachers' goals, resources, beliefs, and knowledge, favoring the successful integration of ICT into the educational environment. TPACK has also proven to be a useful tool for evaluating large-scale initiatives in education, as in the Israel and Rwanda studies. In addition, TPACK has been used as a complement to other models such as Montessori.

From its inception, the TPACK model has aimed to understand teacher professional development in both school and university settings so that technology can be integrated into teaching practices (Mishra \& Koehler, 2006).

This SLR highlights that research on the TPACK model has incorporated students and their families, enriching the model and incorporating new lines of research. It highlights the need to incorporate TPACK studies related to school management teams and to address issues of educational management. It is also necessary to develop studies of the TPACK model in early education in order to relate these results to the primary level.

Regarding the limitations of this SLR, it is necessary to deepen the knowledge of some methodological orientations, model instruments, and information analysis in order to develop new research projects related to the TPACK model. 
In this SLR, only a few databases were considered for review and analysis, which may bias this research. Therefore, it would be advisable that other databases such as ScienceDirect, Sage Journal, Taylor and Francis, Psychinfo, Electronic Sources, and Springer are also included when designing future literature reviews of the TPACK model in primary education.

Author notes: The author approves final version of the article.

Funding: The author received no financial support for the research and/or authorship of this article.

Declaration of interest: The author declares no competing interest.

Data availability: Data generated or analyzed during this study are available from the author on request.

\section{REFERENCES}

Akturk, A. O., \& Ozturk, H. S. (2019). Teachers' TPACK levels and students' self-efficacy as predictors of students' academic achievement. International Journal of Research in Education and Science, 5(1), $283-294$. https://bit.ly/3oLxIB6

Alabbasi, D. (2017, March). Gamifying TPACK: The application of a design-based teaching strategy to enhance teachers' intrinsic motivation toward effective technology integration. In P. Resta, \& S. Smith (Eds.), Proceedings of Society for Information Technology \& Teacher Education International Conference (pp. 2269-2279). Austin, TX, United States. https://www.learntechlib.org/primary/p/177520/

Anderson, T. (2005). Design-based research and its application to a call centre innovation in distance education. Canadian Journal of Learning and Technology 31(2), 69-83. https://doi.org/10.21432/T26K60

Angeli, C., \& Valanides, N. (2009). Epistemological and methodological issues for the conceptualisation, development, and assessment of ICT-TPCK: Advances in technological pedagogical content knowledge (TPCK). Computers \& Education, 52(1), 154-168. https://doi.org/10.1016/j.compedu.2008.07.006

Angeli, C., Voogt, J., Fluck, A., Webb, M., Cox, M., Malyn-Smith, J., \& Zagami, J. (2016). A K-6 computational thinking curriculum framework: Implications for teacher knowledge. Journal of Educational Technology \& Society, 19(3), 47-57. http://ecite.utas.edu.au/110032

Archambault, L. M., \& Barnett, J. H. (2010). Revisiting technological pedagogical content knowledge: Exploring the TPACK framework. Computers \& Education, 55(4), 1656-1662. https://doi.org/10.1016/j.compedu. 2010.07.009

Ardanuy Baró, J. (2012). Breve introducción a la bibliometría [Brief introduction to bibliometrics]. The SCOPUS database and other CBUES e-resources as a research activity management tool; 1. https://is.gd/G4uDNO

Ballesta Pagán, J., Martinez Buendía, J., \& Cespedes Ventura, R. (2017). An integrative model for media literacy and digital competence in primary education. Revista Fuentes [Sources Magazine], 19(2), 139-154. https://idus.us.es/xmlui/handle/11441/72873

Beltrán-Sánchez, J. A., García López, R. I., Ramírez-Montoya, M. S., \& Tánori Quintana, J. (2019). Factores que influyen en la integración del programa de inclusión y alfabetización digital en la docencia en escuelas primarias [Factors that influence the integration of the digital inclusion and literacy program in teaching in primary schools]. Revista Electrónica de Investigación Educativa [Electronic Journal of Educational Research], 21, e31. https://doi.org/10.24320/redie.2019.21.e31.2088

Bingimlas, K. (2018). Investigating the level of teachers' knowledge in technology, pedagogy, and content (TPACK) in Saudi Arabia. South African Journal of Education, 38(3). https://doi.org/10.15700/saje. v38n3a1496

Bolívar, A. (2005). Conocimiento didáctico del contenido y didácticas específicas [Didactic content knowledge and specific didactics]. Profesorado. Revista de Currículum y Formación del Profesorado [Faculty. Curriculum Magazine and Faculty Formation], 9(2), 1-39. http://hdl.handle.net/10481/15256

Brantley-Dias, L., \& Ertmer, P. A. (2013). Goldilocks and TPACK: Is the construct "just right?" Journal of Research on Technology in Education, 46(2), 103-128. https://doi.org/10.1080/15391523.2013.10782615

Cabero Almenara, J., Marín Díaz, V., \& Castaño Garrido, C. (2015). Validación de la aplicación del modelo TPACK para la formación del profesorado en TIC [Validation of the application of the TPACK model for ICT teacher training]. @ Tic. Revista D'innovació Educativa [@ Tic. Educational Innovation Magazine], 14, $13-22$. https://doi.org/10.7203/attic.14.4001 
Chai, C. S., Koh, J. H. L., \& Tsai, C. C. (2013). A review of technological pedagogical content knowledge. Journal of Educational Technology \& Society, 16(2), 31-51. https://eric.ed.gov/?id=EJ1016563

Chapman, A. L., Morgan, L. C., \& Gartlehner, G. (2010). Semi-automating the manual literature search for systematic reviews increases efficiency. Health Information \& Libraries Journal, 27(1), 22-27. https://doi.org/10.1111/j.1471-1842.2009.00865.x

Chen, F. H., Looi, C. K., \& Chen, W. (2009). Integrating technology in the classroom: A visual conceptualisation of teachers' knowledge, goals and beliefs. Journal of Computer Assisted Learning, 25(5), 470-488. https://doi.org/10.1111/j.1365-2729.2009.00323.x

Chen, H. Y., \& Jang, S. J. (2013). Exploring the reasons for using electric books and technologic pedagogical and content knowledge of Taiwanese elementary mathematics and science teachers. Turkish Online Journal of Educational Technology-TOJET, 12(2), 131-141. https://eric.ed.gov/?id=EJ1015403

Cox, S., \& Graham, C. R. (2009). Using an elaborated model of the TPACK framework to analyse and depict teacher knowledge. TechTrends, 53(5), 60-69. https://doi.org/10.1007/s11528-009-0327-1

Da Silva Cristiano, M. A., da Silva, J. B., da Luz Filho, S. S., Bilessimo, S. M. S., Nicolete, P. C., Simão, J. P. S., \& da Mota Alves, J. B. (2015, June). Using TPACK to assess integration of remote experiments in basic education. In 2015 3rd Experiment International Conference (pp. 325-330). https://bit.ly/3o65Rq1

Dikmen, C. H., \& Demirer, V. (2016). Trends in studies on technological pedagogical content knowledge in Turkey between 2009 and 2013 years. Turkish Journal of Education, 5(1), 33-46. https://doi.org/10.19128/ turje.77632

Erdogan, A., \& Sahin, I. (2010). Relationship between math teacher candidates' technological pedagogical and content knowledge (TPACK) and achievement levels. Procedia-Social Behavioral Sciences, 2, 2707-2711. https://doi.org/10.1016/j.sbspro.2010.03.400

Ertmer, P. A., \& Ottenbreit-Leftwich, A. T. (2010). Teacher technology change: How knowledge, confidence, beliefs, and culture intersect. Journal of Research on Technology in Education, 42(3), 255-284. https://doi.org/10.1016/j.compedu.2010.06.002

Graham, C. R. (2011). Theoretical considerations for understanding technological pedagogical content knowledge (TPACK). Computers \& Education, 57(3), 1953-1960. https://doi.org/10.1016/j.compedu.2011. 04.010

Hansen, A., Mavrikis, M., \& Geraniou, E. (2016). Supporting teachers' technological pedagogical content knowledge of fractions through co-designing a virtual manipulative. Journal of Mathematics Teacher Education, 19(2-3), 205-226. https://doi.org/10.1007/s10857-016-9344-0

Harris, J. B., \& Hofer, M. J. (2011). Technological pedagogical content knowledge (TPACK) in action: A descriptive study of secondary teachers' curriculum-based, technology-related instructional planning. Journal of Research on Technology in Education, 43(3), 211-229. https://doi.org/10.1080/15391523.2011.10782570

Heitink, M., Voogt, J., Fisser, P., Verplanken, L., \& van Braak, J. (2017). Eliciting teachers' technological pedagogical knowledge. Australasian Journal of Educational Technology, 33(3). https://doi.org/10.14742/ ajet.3505

Hjalmarson, M. A., \& Diefes-Dux, H. (2008). Teacher as designer: A framework for teacher analysis of mathematical model-eliciting activities. Interdisciplinary Journal of Problem-Based Learning, 2(1). https://doi.org/10.7771/1541-5015.1051

Hughes, J. (2005). The role of teacher knowledge and learning experiences in forming technology-integrated pedagogy. Journal of Technology and Teacher Education, 13(2), 277-302. https://www.learntechlib.org/p/ 26105/

Igbo, H. U., \& Imo, N. T. (2017). Electronic information resource sharing among university libraries in Southern Nigeria: Opportunities and challenges. African Journal of Library Archives and Information Science, 27(1), 77-91. https://bit.ly/3udpr6z

Jang, S. J., \& Tsai, M. F. (2012). Exploring the TPACK of Taiwanese elementary mathematics and science teachers with respect to use of interactive whiteboards. Computers \& Education, 597, 327-338. https://doi.org/10.1016/j.compedu.2012.02.003

Jimoyiannis, A. (2010). Designing and implementing an integrated technological pedagogical science knowledge framework for science teacher's professional development. Computers \& Education, 55(3), 1259-1269. https://doi.org/10.1016/j.compedu.2010.05.022 
Jones, S. J. (2017). Technology in the Montessori classroom: Teachers' beliefs and technology use. Journal of Montessori Research, 3(1), 16-29. https://doi.org/10.17161/jomr.v3i1.6458

Karatas, A., \& Akgun, O. E. (2014). Lise öğretmenlerinin FATiH projesi'ni uygulamaya yönelik teknolojik pedagojik alan bilgisi yeterliliklerinin incelenmesi [Examination of high school teachers' technological pedagogical content knowledge competencies for applying the FATIH project]. Medeniyet Eğitim Araştırmaları Dergisi [Journal of Civilization Educational Research], 1(4), 10-30. https://bit.ly/3EPNqe0

Kazu, I. Y., \& Erten, P. (2014). Teachers' technological pedagogical content knowledge self-efficacies. Journal of Education and Training Studies, 2(2), 126-144. https://doi.org/10.11114/jets.v2i2.261

Kelly, M. (2010, March). Technological pedagogical content knowledge (TPACK): A content analysis of 20062009 print journal articles. In Society for Information Technology \& Teacher Education International Conference (pp. 3880-3888). https://www.learntechlib.org/p/33985/

Kim, C., Kim, M. K., Lee, C., Spector, J. M., \& De-Meester, K. (2013). Teacher beliefs and technology integration. Teaching and Teacher Education, 29, 76-85. https://doi.org/10.1016/j.tate. 2012.08.005

Kitchenham, B. (2004). Procedures for performing systematic reviews. Keele University, Keele, UK, 33(2004), 126. https://is.gd/9FylcB

Kitchenham, B., \& Charters, S. (2007). Guidelines for performing systematic literature reviews in software engineering. https://is.gd/YyizjA

Koehler, M. J., \& Mishra, P. (2005). What happens when teachers design educational technology? The development of technological pedagogical content knowledge. Journal of Educational Computing Research, 32(2), 131-152. https://doi.org/10.2190/0EW7-01WB-BKHL-QDYV

Koehler, M. J., Mishra, P., Kereluik, K., Shin, T. S., \& Graham, C. R. (2014). The technological pedagogical content knowledge framework. In Handbook of research on educational communications and technology (pp. 101111). Springer. https://bit.ly/3HUxHNO

Koehler, M., \& Mishra, P. (2009). What is technological pedagogical content knowledge (TPACK)? Contemporary Issues in Technology and Teacher Education, 9(1), 60-70. https://www.learntechlib.org/p/29544/

Koh, J. H. L., \& Chai, C. S. (2014). Teacher clusters and their perceptions of technological pedagogical content knowledge (TPACK) development through ICT lesson design. Computers \& Education, 70, 22-232. https://doi.org/10.1016/j.compedu.2013.08.017

Lescano, M. Y. (2013). Experiencias de la aplicación de la metodología TPACK usando recursos de la web 2.0 en un colegio técnico secundario [Experiences of the application of the TPACK methodology using web 2.0 resources in a secondary technical school]. TE \& ET, 10, 45-52. http://hdl.handle.net/10915/27732

Lin, T. C., Tsai, C. C., Chai, C. S., \& Lee, M. H. (2013). Identifying science teachers' perceptions of technological pedagogical and content knowledge (TPACK). Journal of Science Education and Technology, 22, 325-336. https://doi.org/10.1007/s10956-012-9396-6

Liu, S. H. (2013). Exploring the instructional strategies of elementary school teachers when developing technological, pedagogical, and content knowledge via a collaborative professional development program. International Education Studies, 6(11), 58-68. https://doi.org/10.5539/ies.v6n11p58

Luik, P., Taimalu, M., \& Suviste, R. (2018). Perceptions of technological, pedagogical and content knowledge (TPACK) among pre-service teachers in Estonia. Education and Information Technologies, 23(2), 741-755. https://doi.org/10.1007/s10639-017-9633-y

Lye, L. T. (2013). Opportunities and challenges faced by private higher education institution using the TPACK model in Malaysia. Procedia-Social Behavioral Sciences, 91, 294-305. https://doi.org/10.1016/j.sbspro. 2013.08.426

Lye, S. Y., Wee, L. K., Kwek, Y. C., Abas, S., \& Tay, L. Y. (2014). Design, customisation and implementation of energy simulation with $5 \mathrm{E}$ model in elementary classroom. Journal of Educational Technology \& Society, 17(3), 121-137. https://is.gd/DtiN47

Maboe, E., Smith, C. G., Banoobhai, M., \& Makgatho, M. (2018). Implementing tablets to teach reading in grade 5. Reading \& Writing, 9(1), 1-10. https://doi.org/10.4102/rw.v9i1.197

Magen-Nagar, N., \& Peled, B. (2013). Characteristics of Israeli school teachers in computer-based learning environments. Journal of Educators Online, 10(1), 1-34. https://doi.org/10.9743/JEO.2013.1.2

Malik, S., Rohendi, D., \& Widiaty, I. (2019). Technological pedagogical content knowledge (TPACK) with information and communication technology (ICT) integration: A literature review. In 5th UPI International Conference on Technical and Vocational Education and Training. https://doi.org/10.2991/ictvet-18.2019.114 
Margerum-Leys, J., \& Marx, R. W. (2002). Teacher knowledge of educational technology: A case study of student/mentor teacher pairs. Journal of Educational Computing Research, 26(4), 427-462. https://doi.org/10.2190/JXBR-2G0G-1E4T-7T4M

Margerum-Leys, J., \& Marx, R. W. (2004). The nature and sharing of teacher knowledge of technology in a student teacher/mentor teacher pair. Journal of Teacher Education, 55(5), 421-437. https://doi.org/10.1177/0022487104269858

Mishra, P., \& Koehler, M. J. (2006). Technological pedagogical content knowledge: A framework for teacher knowledge. Teachers College Record, 108(6), 1017-1054. https://doi.org/10.1177/016146810610800610

Mishra, P., Koehler, M. J., \& Henriksen, D. (2011). The seven trans-disciplinary habits of mind: Extending the TPACK framework towards 21st century learning. Educational Technology, 22-28. https://is.gd/W7FKo0

Moore-Adams, B. L., Jones, W. M., \& Cohen, J. (2016). Learning to teach online: A systematic review of the literature on K-12 teacher preparation for teaching online. Distance Education, 37(3), 333-348. https://doi.org/10.1080/01587919.2016.1232158

Munyengabe, S., Yiyi, Z., Haiyan, H., \& Hitimana, S. (2017). Primary teachers' perceptions on ICT integration for enhancing teaching and learning through the implementation of one laptop per child program in primary schools of Rwanda. Eurasia Journal of Mathematics, Science and Technology Education, 13(11), 7193-7204. https://doi.org/10.12973/ejmste/79044

Niess, M. L. (2005). Preparing teachers to teach science and mathematics with technology: Developing a technology pedagogical content knowledge. Teaching and Teacher Education, 21(5), 509-523. https://doi.org/10.1016/j.tate.2005.03.006

Nordin, H., Davis, N., \& Tengku, T.F. (2013). A case study of secondary pre-service teachers' technological pedagogical and content knowledge mastery level. Procedia-Social Behavioral Sciences, 103, 1-9. https://doi.org/10.1016/j.sbspro.2013.10.300

Ozturk, E., \& Horzum, M. B. (2011). Teknolojik pedagojik içerik bilgisi ölçeği'nin türkçeye uyarlamasi [Turkish adaptation of the technological pedagogical content knowledge scale]. Ahi Evran Üniversitesi Kırşehir Eğitim Fakültesi Dergisi, 12(3), 255-278. https://bit.ly/3gL6zEw

Paidicán, M. (2017). El modelo TPACK y su aporte en la gestión institucional del Colegio Abraham Lincoln de la comuna de Quilpué [The TPACK model and its contribution to the institutional management of the Abraham Lincoln School in the commune of Quilpué] [Tesis de magister, Universidad de Playa Ancha Ciencias de la Educación] [Master's thesis, University of Playa Ancha Educational Sciences].

Paidicán, M. (2019). Modelo Tecno-pedagógico (TPACK) en educación primaria: Una revisión sistemática [Techno-pedagogical model (TPACK) in primary education: A systematic review]. [Master's thesis, Universidad de Granada].

Paneru, D. (2018). Information communication technologies in teaching English as a foreign language: Analysing EFL teachers' TPACK in Czech elementary schools. Center for Educational Policy Studies Journal, 8(3), 141-163. https://doi.org/10.26529/cepsj.499

Petticrew, M., \& Roberts, H. (2008). Systematic reviews in the social sciences: A practical guide. John Wiley \& Sons.

Polly, D., Mims, C., Shepherd, C. E., \& Inan, F. (2010). Evidence of impact: Transforming teacher education with preparing tomorrow's teachers to teach with technology (PT3) grants. Teaching and Teacher Education, 26(4), 863-870. https://doi.org/10.1016/j.tate.2009.10.024

Rodríguez Moreno, J., Agreda Montoro, M., \& Ortiz Colón, A. M. (2019). Changes in teacher training within the TPACK model framework: A systematic review. Sustainability, 11(7), 1870. https://doi.org/10.3390/ su11071870

Roig-Villa, R., Mengual-Andrés, S., \& Quinto-Medrano, P. (2015). Primary teachers' technological, pedagogical and content knowledge. Comunicar [To Communicate], 23(45). https://doi.org/10.3916/C45-2015-16

Rosenberg, J. M., \& Koehler, M. J. (2015). Context and technological pedagogical content knowledge (TPACK): A systematic review. Journal of Research on Technology in Education, 47(3), 186-210. https://doi.org/10.1080/15391523.2015.1052663

Roussinos, D., \& Jimoyiannis, A. (2019). Examining primary education teachers' perceptions of TPACK and the related educational context factors. Journal of Research on Technology in Education, 51(4), 377-397. https://doi.org/10.1080/15391523.2019.1666323 
Sáez-López, J. M., \& Cózar, R. (2017). Programación visual por bloques en educación primaria: aprendiendo y creando contenidos en ciencias sociales [Visual programming by blocks in primary education: learning and creating content in social sciences]. Revista Complutense de Educación [Complutense Journal of Education], 28(2), 409-426. https://doi.org/10.5209/rev_RCED.2017.v28.n2.49381

Schmidt, D. A., Baran E., Thompson A. D., Mishra P., Koehler M. J., \& Shin T. S. (2009). Technological pedagogical content knowledge (TPACK): The development and validation of an assessment instrument for preservice teachers. Journal of Research on Technology in Education, 42, 123-150. https://doi.org/10.1080/15391523.2009.10782544

Schmidt, D., Sahin, E. B., Thompson, A., \& Seymour, J. (2008, March). Developing effective technological pedagogical and content knowledge (TPACK) in PreK-6 teachers. In Society for Information Technology \& Teacher Education International Conference (pp. 5313-5317). Association for the Advancement of Computing in Education (AACE). https://www.learntechlib.org/p/28124/

Shulman, L. S. (1986). Those who understand: knowledge growth in teaching. Educational Researcher, 15(2), 414. https://doi.org/10.3102/0013189X015002004

Shulman, L. S. (1987). Knowledge and teaching: Foundations of the new reform. Harvard Educational Review, 57(1), 1-21. https://doi.org/10.17763/haer.57.1.j463w79r56455411

So, H. J., \& Kim, B. (2009). Learning about problem based learning: Student teachers integrating technology, pedagogy and content knowledge. Australasian Journal of Educational Technology, 25(1), 101-116. https://doi.org/10.14742/ajet.1183

Tai, S. J. D. (2015). From TPACK-in-action workshops to classrooms: CALL competency developed and integrated. Language Learning \& Technology, 19(1), 139-164. https://eric.ed.gov/?id=EJ1051726

Torres, C. A. B. (2006). Metodología de la investigación: Para administración, economía, humanidades y ciencias sociales [Research methodology: For administration, economics, humanities and social sciences]. Pearson.

Vatanartiran, Ş. K. S. (2015). Primary school teachers' technological pedagogical content knowledge. Elementary Education Online, 14(3), 1017-1028. https://bit.ly/2NAdWmz

Voogt, J., Fisser, P., Pareja Roblin, N. N., Tondeur, J., \& van Braak, J. (2013). Technological pedagogical content knowledge-a review of the literature. Journal of Computer Assisted Learning, 29(2), 109-121. https://doi.org/10.1111/j.1365-2729.2012.00487.x

Wang, W., Schmidt-Crawford, D., \& Jin, Y. (2018). Preservice teachers' TPACK development: A review of literature. Journal of Digital Learning in Teacher Education, 34(4), 234-258. https://doi.org/10.1080/21532974.2018.1498039

Willermark, S. (2018). Technological pedagogical and content knowledge: A review of empirical studies published from 2011 to 2016. Journal of Educational Computing Research, 56(3), 315-343. https://doi.org/10.1177/0735633117713114

Wong, L. H., Chai, C. S., Zhang, X., \& King, R. B. (2014). Employing the TPACK framework for researcher-teacher co-design of a mobile-assisted seamless language learning environment. IEEE Transactions on Learning Technologies, 8(1), 31-42. https://doi.org/10.1109 / TLT.2014.2354038

Yeh, Y. F., Chan, K. K. H., \& Hsu, Y. S. (2021). Toward a framework that connects individual TPACK and collective TPACK: A systematic review of TPACK studies investigating teacher collaborative discourse in the learning by design process. Computers \& Education, 171, 104238. https://doi.org/10.1016/j.compedu. 2021.104238

Young, J. R. (2016). Unpacking TPACK in mathematics education research: A systematic review of metaanalyses. International journal of educational methodology, 2(1), 19-29. https://doi.org/10.12973/ijem.2.1. 19

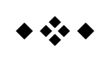

